\title{
RUANG TUMBUH UNTUK PENYU DAN TERUMBU KARANG DENGAN METODE KAMUFLASE
}

\author{
Bernadette Adelia Oktaviani ${ }^{11}$, Franky Liauw ${ }^{2)}$ \\ 1)Program Studi S1 Arsitektur, Fakultas Teknik, Universitas Tarumanagara, oktaviani.adelia2@yahoo.com \\ 2) Program Studi S1 Arsitektur, Fakultas Teknik, Universitas Tarumanagara, frankyl@ft.untar.ac.id
}

Masuk: 02-07-2021, revisi: 13-08-2021, diterima untuk diterbitkan: 23-10-2021

\begin{abstract}
Abstrak
Indonesia sebagai negara kepulauan sangat dipengaruhi dan mempengaruhi perairan di sekitarnya. Kondisi perairan di Indonesia sangat mempengaruhi ekosistem laut baik flora maupun fauna. Penyu dan terumbu karang merupakan perwakilan dari flora dan fauna yang terdampak dari kondisi ekosistem laut. Sebagian besar jenis penyu terdapat di Indonesia dan Indonesia berada di segitiga terumbu karang sehingga terdapat diversifikasi terumbu karang yang tinggi. Namun, kondisi ini seringkali tidak disadari baik oleh masyarakat, wisatawan, maupun nelayan. Ruang Tumbuh untuk Penyu dan Terumbu Karang merupakan fasilitas konservasi untuk menambah ruang tumbuh bagi penyu dan terumbu karang dan dilengkapi dengan kegiatan pariwisata sebagai usaha untuk meningkatkan kesadaran masyarakat dan pengunjung akan pentingnya penyu dan terumbu karang bagi ekosistem laut. Proyek ini berlokasi di Pulau Kelapa dua, Kepulauan Seribu, Jakarta Utara. Dalam proyek ini, metode desain yang diterapkan adalah metode desain kamuflase untuk meningkatkan kenyamanan penyu dalam melakukan proses bertelur di area pantai. Dari metode ini terdapat beberapa poin penting yaitu alam, vegetasi, penglihatan, bentuk, dan warna. Penerapannya berdasarkan metode tersebut dapat dilihat melalui material yang alami sehingga menyatu dengan alam sekitar, vegetasi untuk meningkatkan potensi penyu bertelur dan mengkamuflase, serta bentuk melengkung untuk meniru penyu. Dengan begitu, dapat meningkatkan rasa cinta dan kesadaran manusia akan alam.
\end{abstract}

Kata kunci: ekosistem laut; kamuflase ; penyu; terumbu karang

\begin{abstract}
Indonesia as an archipelago country is influenced and influences the sea. The condition of the sea in Indonesia greatly affects the marine ecosystem, both in flora and fauna. Sea turtles and coral reefs are representatives of flora and fauna that are affected by the marine ecosystem. Most type of sea turtles can be found in Indonesia and Indonesia is located in the coral triangle so there is high coral reef diversification. However, this condition is often being neglected by the tourists and fishermen. This project is a conservation facility to increase the growth of sea turtles and coral reefs and complemented by tourism activities as an effort to increase visitors and awareness of the importance of sea turtles and coral reefs for marine ecosystems. This project is located in Kelapa Dua Island, Thousand Islands, North Jakarta. In this project the design method applied is camouflage, this method is chosen to increase comfortability for the sea turtles during their nesting process in the coastal area. From this method, there are several important points such as nature, vegetation, vision, shape, and color. Its application based on this method can be seen through the natural materials that are used in this building so it blends with the surrounding environment, vegetation to increase the potential for turtles to lay eggs and camouflaging the building, and curved shapes to mimic turtles. Therefore, it can increase the love and human consciousness of nature.
\end{abstract}

Keywords: camouflage; coral reef; marine ecosystem; sea turtle 


\section{PENDAHULUAN}

Indonesia adalah negara kepulauan sehingga kondisi daratan sangat dipengaruhi oleh perairan. Diperkirakan sekitar $60 \%$ dari total penduduk di Indonesia menjadikan laut sebagai mata pencaharian utama dan tempat tinggal, serta beraktivitas (Habibie, Muhammad dan Nuraini, 2014). Indonesia juga diakui sebagai pusat keragaman hayati dunia terutama dalam biota-biota laut dan pesisir (Tomasick et al., 2016). Namun, kondisi ini seringkali diabaikan oleh masyarakat maupun wisatawan sehingga menimbulkan kerusakan dan penurunan pada kualitas ekosistem laut. Penurunan populasi sumber daya laut yang terjadi akibat eksploitasi berlebihan, penyalahgunaan, dan perubahan iklim (Hoegh-Guldberg et al., 2015). Indonesia telah menjadi rumah bagi enam dari total tujuh spesies penyu yang tersisa di dunia ini (Adnyana dan Hitipeuw, 2009). Spesies penyu di antaranya adalah penyu hijau, penyu sisik, penyu lekang, penyu belimbing, penyu tempayan, dan penyu pipih. Penyu merupakan salah satu perwakilan fauna yang mengalami kelangkaan, sedangkan terumbu karang sebagai flora ekosistem laut yang menunjang kehidupan spesies laut lainnya. Letak Indonesia yang berada di wilayah pusat segitiga terumbu karang dunia disebut The Coral Triangle, dengan spesies terumbu karang terluas (Hadi et al., 2020). Oleh karena itu, Indonesia yang merupakan negara maritim seharusnya mampu menjaga dan merawat keanekaragaman hayati yang dimiliki.

Kepulauan Seribu memiliki potensi pengembangbiakan penyu dan merupakan habitat dari penyu sisik. Pulau Kelapa Dua, Kepulauan Seribu memiliki potensi penyu ditambah adanya kerusakan terumbu karang. Selain itu, pulau dengan luas 1,9 hektar ini memiliki fungsi sebagai wisata konservasi dan lokasi wisata budaya (Badan Pusat Statistik Kabupaten Kepulauan Seribu, 2018). Kedua potensi ini seharusnya menjadi perhatian bagi masyarakat sekitar dikarenakan mayoritas penduduk di Kepulauan Seribu menggantungkan hidupnya pada ekosistem laut dengan bekerja sebagai nelayan (Sosilowati et al., 2017). Dengan adanya peningkatan kesadaran oleh masyarakat dan wisatawan ekosistem laut akan terjaga dan terhindar dari kepunahan. Arsitektur dapat ikut berperan dalam upaya menjaga ekosistem laut dan menumbuhkan rasa kepedulian bagi masyarakat maupun wisatawan. Dengan begitu, kelestarian ekosistem laut dapat terjaga.

Berdasarkan pembahasan tersebut, terdapat rumusan masalah yaitu bagaimana mendesain ruang tumbuh untuk penyu dan terumbu karang, serta bagaimana penerapan metode kamuflase dalam sebuah rancangan desain arsitektur. Melalui metode kamuflase diharapkan manusia dapat lebih memperhatikan kondisi suatu ekosistem. Dengan begitu, dampak negatif dari kegiatan manusia bagi ekosistem maupun lingkungannya dapat diminimalisir. Permasalahan ini mengajak manusia untuk memberikan perhatian lebih bagi perubahan kondisi ekosistem akibat kegiatan manusia. Proyek yang diusulkan berupa ruang konservasi penyu dan terumbu karang dengan kegiatan wisata dan edukasi yang merupakan bentuk ajakan dan usaha dalam meningkatkan kepedulian manusia pada alam. Proses perancangan akan mempertimbangkan kepentingan penyu dan terumbu karang sebagai perhatian utama guna menyadarkan manusia akan kondisi lingkungan sekitarnya yang semakin terancam. Dengan perencanaan Ruang Tumbuh untuk Penyu dan Terumbu Karang diharapkan dapat menjadi bagian dalam pelestarian ekosistem laut dan menciptakan keseimbangan antara manusia dengan alam sekitarnya.

\section{KAJIAN LITERATUR}

\section{Ekologi}

Ekologi adalah suatu ilmu yang mempelajari organisme yang ada pada lingkungan sekitarnya. Ekologi mencakup beberapa satuan makhluk hidup atau organisme. Dalam ekologi terdapat hirarki yang dimulai dari tingkatan terkecil yaitu molekul, sel, jaringan, organ, sistem organ, individu, populasi, komunitas, ekosistem, dan biosfer. Terdapat komponen biotik atau hidup dan abiotik atau non hidup dalam ekologi dan seluruh komponen ini saling berinteraksi (Barlian dan Umar, 2007). 


\section{Ekosistem}

Ekosistem adalah suatu sistem yang bersifat fungsional dan membahas proses interaksi organisme hidup dengan lingkungannya. Faktor yang mempengaruhi perkembangan ekosistem adalah ketersediaan sumber daya, faktor pembatas fisik, dan kemampuan dari organismenya. Ekosistem dibagi berdasarkan caranya terbentuk dan keberadaannya. Berdasarkan cara terbentuknya terdapat ekosistem alami dan buatan. Sedangkan, ekosistem dapat menyesuaikan dengan letaknya yaitu pada perairan dan daratan. Ekosistem laut adalah ekosistem yang menurut wilayahnya berada di tepi laut dan daerah tropis dengan kadar garam yang tinggi (Mukharomah, 2021).

Penyu adalah kura-kura laut yang memiliki sepasang tungkai depan yang berupa kaki pendayung yang memungkinkan untuk berenang. Penyu mampu bermigrasi dengan jarak ribuan kilometer antara daerah tempat makan dan tempat bertelur. Penyu dapat menempuh jarak 3.000 kilometer dalam 58 hingga 73 hari. Sebagian waktu hidup penyu dihabiskan di laut tetapi induknya akan menuju ke daratan ketika waktunya untuk bertelur. Dalam waktu dua sampai empat tahun sekali induk penyu akan datang ke pantai sejumlah empat sampai tujuh kali untuk meletakan ratusan butir telurnya (Adnyana dan Hitipeuw, 2009). Berdasarkan Peraturan Pemerintah (PP) Nomor 7 tahun 1999 tentang Pengawetan Jenis Tumbuhan dan Satwa, seluruh jenis penyu di Indonesia telah dilindungi.

Terumbu karang adalah endapan zat kapur yang merupakan hasil metabolisme dari ribuan hewan karang, sedangkan karang adalah hewan yang tersusun atas puluhan atau jutaan individu yang disebut polip. Karang dibagi menjadi dua macam yaitu karang batu dan karang lunak. Karang batu terbentuk karena adanya kalsium karbonat, sedangkan karang lunak berbentuk seperti tanaman. Manfaat karang sebagai tempat hidup dan pangan bagi ikan, serta menjadi pelindung bagi makhluk laut dan pantai dari hempasan ombak (Salim, 2012).

\section{Konservasi dan Pariwisata}

Berdasarkan Undang-Undang Nomor 5 Tahun 1990 tentang Konservasi Sumber Daya Alam Hayati Pasal 1 ayat 2, konservasi adalah pengelolaan dan pemanfaatan sumber daya alam yang dilakukan secara bijaksana untuk menjadi keberlanjutan. Bentuk konservasi dapat dibagi menjadi dua yaitu konservasi in situ dan ex situ, konservasi in situ berarti kegiatan konservasi dilakukan di dalam habitatnya sedangkan konservasi ex situ berarti kegiatan konservasi dilakukan di luar habitat aslinya. Pariwisata adalah kegiatan dan perjalanan yang dilakukan untuk rekreasi atau berlibur. Berdasarkan Undang-Undang No. 10 Tahun 2009, usaha pariwisata adalah usaha yang menyediakan barang dan jasa bagi pemenuhan kebutuhan wisatawan. Pariwisata dapat dibedakan berdasarkan objeknya yaitu objek wisata alam, wisata sosial budaya, dan wisata minat khusus.

Konservasi dan pariwisata adalah usaha dalam penggabungan antara aktivitas konservasi sebagai objek wisata dengan meminimalisir ancaman bagi keanekaragaman hayati. Kegiatan ini menghubungan pariwisata yang berkelanjutan dengan komunitas dan konservasi. Kegiatan pariwisata ini berusaha meningkatkan kesadaran wisatawan akan kerusakan lingkungan. Selain itu, kegiatan pariwisata konservasi juga mengajak langsung masyarakat untuk melakukan konservasi terhadap lingkungan yang mengalami kerusakan (Humke, 2011).

\section{Ruang Tumbuh}

Berdasarkan Kamus Besar Bahasa Indonesia, Ruang adalah rongga atau sela-sela antara dua tiang atau empat tiang (Kemendikbud, 2021). Sebuah ruang adalah tempat yang dapat memberi perlindungan bagi manusia maupun makhluk hidup lainnya. Sedangkan, arti dari kata tumbuh adalah sebuah perkembangan menjadi lebih besar ataupun sempurna (Kemendikbud, 2021). Tumbuh dapat juga diartikan sebagai kesempatan untuk memberikan kehidupan bagi makhluk hidup. Dengan begitu, ruang tumbuh adalah sebuah tempat yang dapat memberikan peluang 
hidup maupun berkembang biak serta melindungi kehidupan berbagai makhluk hidup dari kepunahan maupun ancaman.

\section{Metode Kamuflase}

Dalam Kamus Besar Bahasa Indonesia, Kamuflase adalah perubahan, penyesuaian bentuk, sikap, maupun warna sebagai usaha untuk perlindungan diri atau mengelabui (Kemendikbud, 2021). Penggunaan teknik kamuflase meminimalisir bentuk maupun volume suatu bangunan terkait dengan pengenalan dan asumsi akan visibilitas dari suatu bangunan (Mohamed, 2014). Kamuflase berasal dari Bahasa Perancis yaitu camoufler yang berarti menyamar. Kamuflase adalah penampilan diri yang tersamarkan karena adanya kondisi atau alat yang membuat beberapa bagian atau keseluruhan menjadi tersembunyi (Sutanto, 2020). Metode diterapkan melalui pengelolaan ruang luar terutama pada pemilihan vegetasi yang harus menyesuaikan dengan kondisi lingkungan sekitarnya. Kondisi sekeliling area perancangan menjadi inspirasi utama dalam pemilihan bentuk, warna, dan material. Penggunaan metode kamuflase ini juga harus menyesuaikan dengan kenyamanan untuk penyu bertelur. Kenyamanan penyu bertelur dapat ditingkatkan melalui beberapa hal yaitu pencahayaan, suhu, kemiringan, dan kebisingan. Kamuflase dan kenyamanan penyu menjadi fokus dalam proses perancangan.

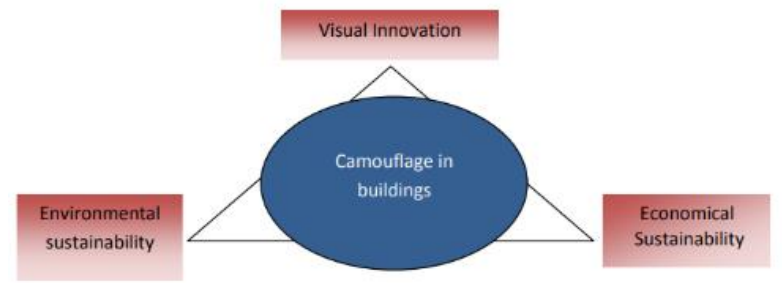

Gambar 1. Diagram Kamuflase dalam Bangunan Sumber: Mohamed, 2014

Penggunaan kamuflase dalam bangunan dapat berhubungan dengan inovasi visual bangunan dan memperhatikan keberlanjutan bagi lingkungan maupun secara ekonomi. Penggunaan material dalam proses perancangan harus mampu mengurangi dampak negatif bagi lingkungan. Selain itu, secara perekonomian memfokuskan pada kemudahan suatu material untuk diperoleh, penggunaan kembali, dan multifungsi dari suatu elemen dalam bangunan. Dengan begitu, kamuflase dapat bekerja sama menghasilkan suatu bentuk visual yang inovatif dan menggunakan material yang alami, serta memaksimalkan pengolahan dan penggunaan ruang.

\section{METODE}

\section{Metode Pengumpulan Data}

Data diperoleh secara kualitatif dengan studi pustaka yang terkait dengan teori-teori yang akan dibahas. Studi pustaka didapat dari jurnal, karya ilmiah dan buku. Dengan adanya pengertian dan pemahaman yang didapat kemudian akan diaplikasikan sebagai pemahaman dasar dalam menciptakan program dan desain yang mampu meningkatkan kesadaran akan lingkungan. Berdasarkan studi pustaka, wisatawan di Kepulauan Seribu lebih memilih kegiatan yang menimbulkan interaksi dengan teman baru (Palenteng, 2017).

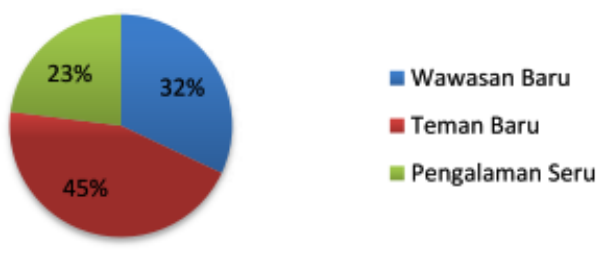

Gambar 2. Diagram Kegiatan Nilai Tambah Sumber: Palenteng, 2017 
Data tersebut dapat menjadi acuan dalam pembentukan ruang dan kegiatan di dalam proyek perancangan. Ruang-ruang harus menimbulkan interaksi antar pengunjung sehingga tidak hanya menciptakan pengalaman yang seru tetapi juga meningkatkan posibilitas terciptanya komunikasi. Beberapa ruang diantaranya adalah ruang collaborative research, ruang multifungsi, lounge, dan area makan. Collaborative research adalah ruang penelitian yang diciptakan untuk memaksimalkan kolaborasi antara pengunjung dan peneliti. Ruang multifungsi dibuat terbuka dengan area duduk di bagian tengah sehingga interaksi dari berbagai kegiatan di sekelilingnya dapat terjadi. Lounge dan area makan diletakkan pada bagian depan dengan harapan seluruh pengunjung dapat mengaksesnya. Melalui pendekatan metode desain kamuflase yang memfokuskan untuk meminimalisir pengenalan penyu terhadap bangunan perancangan. Bangunan yang dirancang harus menjadikan kenyamanan penyu sebagai fokus utama. Kenyamanan penyu ini terkait dengan pengenalan penyu akan lingkungan sekitarnya. Oleh karena itu, kondisi lingkungan maupun bangunan sekitarnya harus tersamarkan sehingga penyu dapat melangsungkan aktivitasnya tanpa terganggu. Selain itu, metode kamuflase diharapkan dapat mengurangi dampak negatif dari bangunan bagi pertumbuhan penyu dan terumbu karang di sekitarnya. Dengan begitu, proses berkembang biak dari penyu dan terumbu karang dapat terus berlangsung meskipun terdapat kegiatan di sekelilingnya.

\section{DISKUSI DAN HASIL}

\section{Kriteria Desain Ruang Tumbuh}

Ruang tumbuh bagi makhluk hidup berkaitan dengan kenyamanan dan perlindungan dari ancaman ataupun kerusakan yang timbul akibat perubahan kondisi lingkungan. Kenyamanan bagi penyu berkaitan dengan kondisi lingkungan yaitu vegetasi, pencahayaan, suhu, dan kemiringan dari lingkungan sekitar tempat bertelur dan pantai. Sedangkan, dalam penyediaan ruang tumbuh untuk terumbu karang akan dilakukan konservasi secara langsung atau in situ oleh pengunjung pada area yang memiliki kerusakan terumbu karang di sekitar pulau. Dengan begitu, dalam proses desain akan lebih memfokuskan pada maksimalisasi kenyamanan penyu karena terdampak secara langsung dengan bangunan.

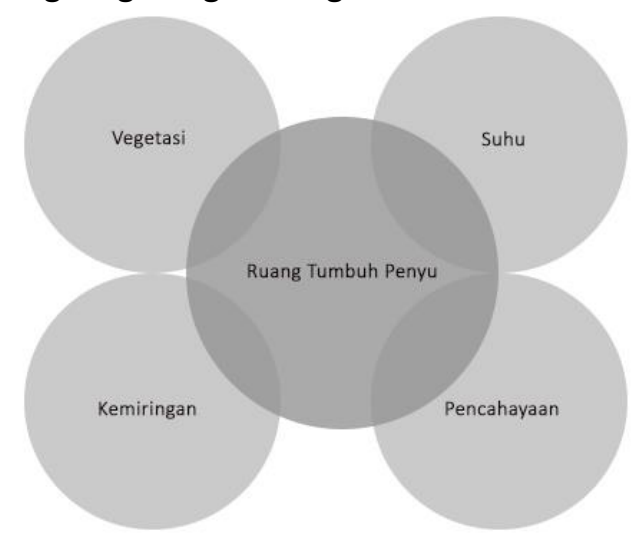

Gambar 3. Diagram Ruang Tumbuh Penyu Sumber: Penulis, 2021

Dalam peningkatan kenyamanan penyu maka ruang tumbuh yang dibentuk harus memperhatikan empat aspek tersebut. Vegetasi yang mampu meningkatkan pertumbuhan penyu diantaranya adalah pohon cemara laut, pandan laut, dan calophyllum. Jenis pohon tersebut dapat meningkatkan kelembaban, kestabilan pada pasir, dan rasa aman bagi penyu saat menggali lubang untuk bersarang dan bertelur (Ridhwan, 2017). Pohon juga dapat menjadi salah satu elemen dalam mengkamuflasekan bangunan. Selain itu, penyu memiliki sensitivitas yang tinggi terhadap pencahayaan sehingga selama proses peneluran ataupun saat malam hari pencahayaan buatan dari bangunan harus diminimalisir (Moein dan Musick, 2002). Suhu dan kemiringan harus memiliki stabilitas sehingga penyu dapat merasa nyaman selama proses 
bertelur. Kondisi suhu sekitar pantai $24^{\circ} \mathrm{C}$ hingga $33^{\circ} \mathrm{C}$ dapat bertelur dan kemiringan pada area pantai umumnya berada dibawah $30^{\circ}$ (Langunan et al., 2017).

\section{Penyesuaian Ruang Tumbuh dengan Kamuflase}

Berdasarkan metode desain kamuflase maka disesuaikan dengan kondisi lingkungan sekitar agar dapat memaksimalkan proses desain. Kondisi lingkungan menjadi pengaruh penting dalam proses desain karena kenyamanan penyu yang bergantung dengan sekelilingnya. Selain itu, metode kamuflase harus menjadikan sekeliling sebagai objek utama untuk peniruan, baik secara bentuk, warna, dan material. Tabel berikut akan menjelaskan tentang desain terkait penyesuaian dengan kriteria kamuflase dan kenyamanan penyu.

Tabel 1. Penyesuaian Kriteria Desain dengan Metode Kamuflase

\begin{tabular}{|c|c|c|c|}
\hline No. & Tujuan & & Kriteria \\
\hline 1. & \multirow{3}{*}{ Kamuflase } & Bentuk & $\begin{array}{l}\text { Berdasarkan Peraturan Daerah Nomor } 1 \\
\text { Tahun } 2014 \text { bangunan berada 1,5 meter di } \\
\text { atas tanah (panggung). }\end{array}$ \\
\hline 2. & & Warna & $\begin{array}{l}\text { Menggunakan warna yang telah ada di area } \\
\text { sekitar seperti hijau, coklat, dan krem }\end{array}$ \\
\hline 3. & & Material & $\begin{array}{l}\text { Menggunakan material yang mudah didapat } \\
\text { (batu bata, kayu kelapa dan bambu plester) }\end{array}$ \\
\hline 4. & $\begin{array}{l}\text { Kamuflase, Ruang } \\
\text { Tumbuh }\end{array}$ & Vegetasi & $\begin{array}{l}\text { Vegetasi yang dapat menarik penyu dan } \\
\text { menjadi objek kamuflase }\end{array}$ \\
\hline 5. & \multirow{4}{*}{ Ruang Tumbuh } & Pencahayaan & $\begin{array}{l}\text { Meminimalisir penggunaan cahaya buatan di } \\
\text { malam hari }\end{array}$ \\
\hline 6. & & Suhu & $\begin{array}{l}24^{\circ} \mathrm{C} \text { hingga } 33^{\circ} \mathrm{C} \text { adalah suhu yang cocok } \\
\text { untuk bertelur }\end{array}$ \\
\hline 7. & & Kemiringan & $\begin{array}{lcc}\text { Kemiringan maksimal } 30^{\circ} \text { untuk } \\
\text { meningkatkan kenyamanan bertelur }\end{array}$ \\
\hline 8. & & Kebisingan & $\begin{array}{l}\text { Meminimalisir kebisingan karena penyu } \\
\text { sensitif terhadap suara }\end{array}$ \\
\hline
\end{tabular}

Sumber: Rangkuman dari Adnyana dan Hitipeuw (2009)

Tabel 2. Metode Kamuflase dalam Desain Bangunan dan Lingkungan Sekitar

\begin{tabular}{|c|c|c|}
\hline No. & Kriteria & Desain \\
\hline 1. & Bentuk & $\begin{array}{l}\text { Menggunakan bentuk rumah panggung untuk menyesuaikan } \\
\text { dengan peraturan dan kondisi sekelilingnya }\end{array}$ \\
\hline 2. & Warna & $\begin{array}{l}\text { Pengaplikasian warna dari sekeliling lingkungannya yaitu pasir } \\
\text { dan pepohonan }\end{array}$ \\
\hline 3. & Material & $\begin{array}{l}\text { Memanfaatkan pasir untuk membentuk kontur pada bangunan } \\
\text { dan penggunaan material yang mudah didapat sehingga dapat } \\
\text { memanfaatkan tenaga kerja lokal }\end{array}$ \\
\hline 4. & Vegetasi & $\begin{array}{l}\text { Pohon cemara laut, pohon pandan laut dan pohon calophyllum } \\
\text { dapat meningkatkan potensi penyu bertelur sekaligus } \\
\text { bermanfaat untuk mengkamuflase bangunan }\end{array}$ \\
\hline 5. & Pencahayaan & $\begin{array}{l}\text { Meminimalisir penggunaan cahaya buatan di malam hari untuk } \\
\text { meningkatkan kenyamanan penyu bertelur }\end{array}$ \\
\hline 6. & Suhu & Suhu dan kemiringan di area sekitar sudah sesuai untuk \\
\hline 7. & Kemiringan & kenyamanan penyu \\
\hline 8. & Kebisingan & Pohon dapat menjadi buffer bagi area peneluran \\
\hline
\end{tabular}

Sumber: Rangkuman dari Moein dan Musick (2002) dan Ridhwan (2017) 
Penyesuaian kriteria desain dengan upaya kamuflase menjadikan proses peningkatan pertumbuhan dan perkembang biakan penyu menjadi maksimal. Kegiatan dalam bangunan dapat mengacu pada kenyamanan penyu agar manusia dan penyu dapat tetap berdampingan. Dengan begitu, penggunaan bangunan dapat maksimal bagi manusia maupun penyu tanpa ada yang terdampak negatif dari keberadaan bangunan tersebut.

\section{Proses Transformasi Desain pada Massa Bangunan}

Transformasi dilakukan dengan tahap awal yang menyesuaikan dengan peraturan pembangunan terutama pada Garis Sempadan Pantai yaitu sejauh 10 meter dan perkiraan kenaikan permukaan air laut saat pasang $110 \mathrm{~cm}$ dan saat terendah atau surut mencapai $30 \mathrm{~cm}$ dari permukaan laut (Yudhantoko et al., 2016). Pemahaman akan GSP ini dapat menjadi potensi sebagai perluasan area bertelur bagi penyu.

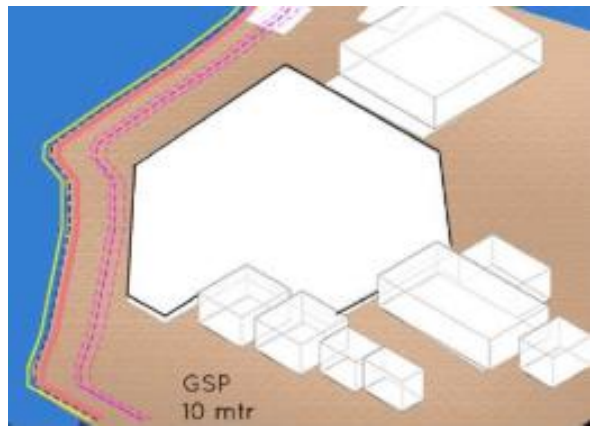

Gambar 4. Penyesuaian dengan GSP Sumber: Penulis, 2021

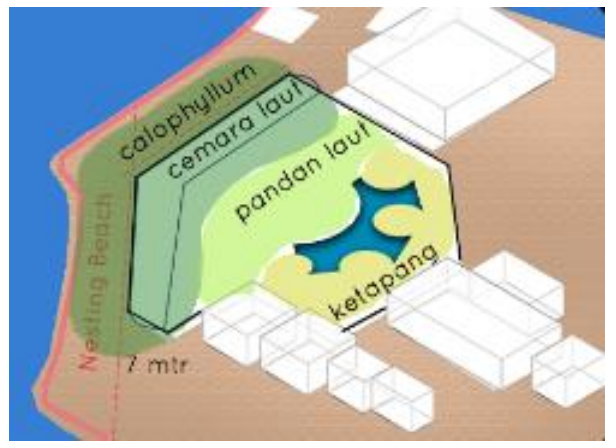

Gambar 5. Penentuan Vegetasi Sumber: Penulis, 2021

Terdapat beberapa vegetasi yang dapat memberikan manfaat bagi penyu dan pengunjung. Pohon pandan laut diletakkan di tengah karena memiliki wangi sehingga meningkatkan kenyamanan pengunjung. Selain itu, pohon ketapang berdekatan dengan air karena dapat menurunkan ph air. Sedangkan, pohon cemara laut dan calophyllum berada di dekat nesting beach karena mengikat butiran pasir menjadi padat sehingga cocok untuk area peneluran (Dewi dan Yuniartik, 2019). Lalu, daun dari pohon calophyllum memiliki helaian daun yang besar dengan begitu dapat meminimalisir penyebaran kebisingan terhadap area nesting beach (Roemantyo et al., 2012).

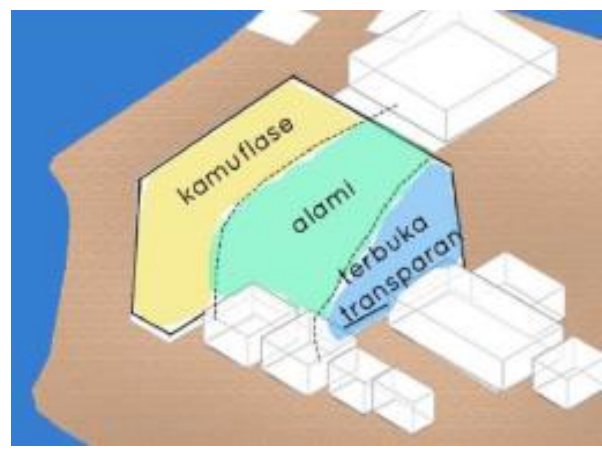

Gambar 6. Konsep Desain

Sumber: Penulis, 2021

Area yang berdekatan dengan nesting beach akan menggunakan material yang meminimalisir potensi terlihat dan memanfaatkan pohon sebagai elemen kamuflase. Lalu, area tengah menggunakan bambu dan batu untuk menekankan elemen alam, sedangkan area terdepan lebih bersifat terbuka untuk mengajak pengunjung melakukan eksplorasi ke dalam tapak dan bangunan. 


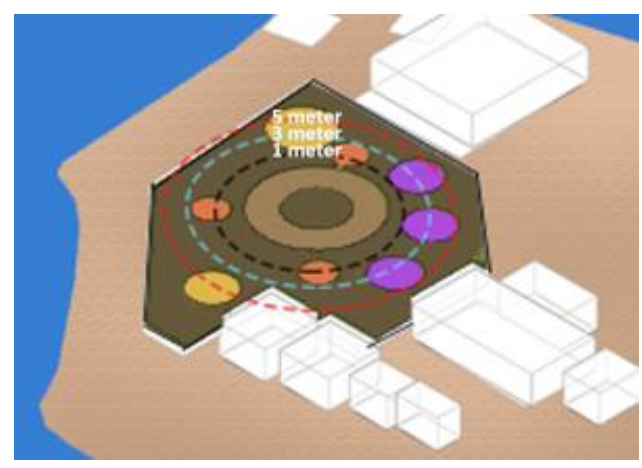

Gambar 7. Pengaturan Zoning

Sumber: Penulis, 2021

Live learning space sebagai radius satu meter untuk memudahkan aksesibilitas pengunjung. Area lounge, open exhibition, dan collaborative research berada di radius tiga meter untuk memberikan jarak agar pengunjung dapat menikmati suasana lingkungan di sekelilingnya. Sea turtle conservatory dan treatment room lebih berjarak yaitu lima meter untuk membatasi akses dikarenakan kegiatannya membutuhkan pengawasan. Ketiga radius tersebut dapat menjadi pemisah akses pengunjung terutama pada ruang-ruang yang membutuhkan pengawasan dan kesadaran tinggi dari pengunjung akan kondisi penyu terkait. Radius tersebut menjadi pembatas karena terkait jarak pencapaiannya, pada jarak satu meter dapat dicapai dengan tiga hingga lima langkah kaki. Sendangkan, pada area dengan radius tiga meter membutuhkan tiga kali lipat jumlah langkah kaki. Begitupun dengan jarak lima meter yang diberikan sebagai area terjauh. Dengan begitu, kondisi penyu tersebut pengendalian pengunjung menjadi pengaruh penting agar meminimalisir kebisingan sehingga meningkatkan kenyamanan bagi penyu dalam proses bertelur dan perawatan.

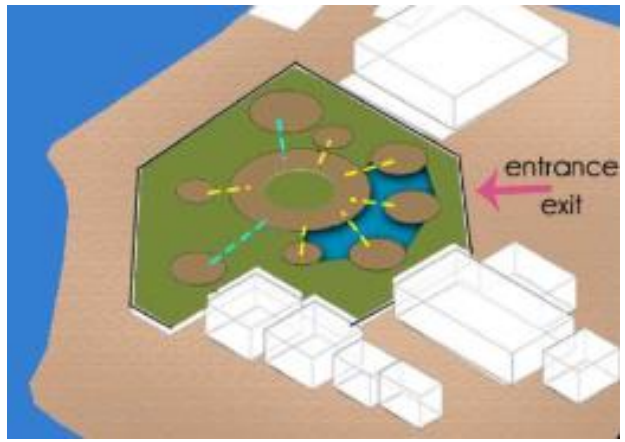

Gambar 8. Unsur Air dan Sirkulasi dalam Tapak Sumber: Penulis, 2021

Unsur air diletakkan pada area depan tapak agar setiap pengunjung dapat mengakses area air yang berfungsi sebagai penangkaran penyu dan beberapa hewan air lainnya. Selain itu, area air dapat meningkatkan kesejukan udara dari penguapan air sehingga menjadi mampu menarik pengunjung. Dengan adanya area kolam, pengunjung dapat berpartisipasi dalam proses perawatan penyu. Salah satu caranya adalah melalui pemberian makanan pada penyu sehingga menimbulkan rasa kepedulian pada hewan laut terutama penyu. Akses berwarna kuning diperuntukan bagi pengunjung, pengelola, maupun peneliti. Sedangkan, akses berwarna biru lebih terbatas karena terhubung dengan ruang konservasi dan perawatan. Ruang tersebut didominasi oleh akses dari peneliti dan pengelola. Pengunjung tetap dapat mengakses namun, terdapat pengendalian jumlah pengunjung. 


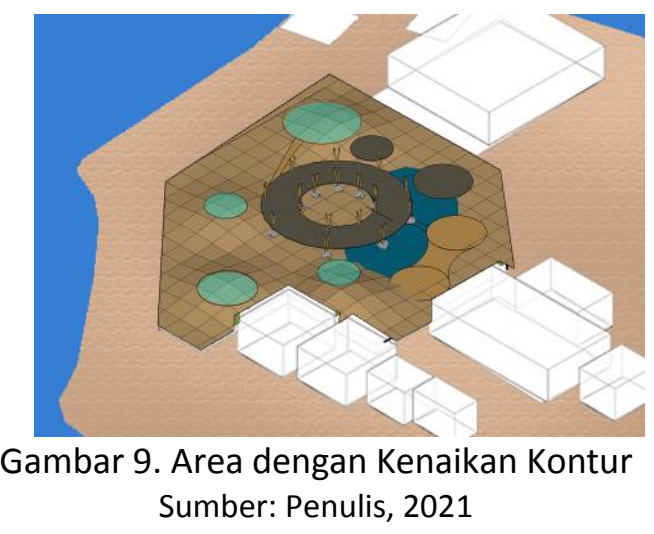

Pada beberapa titik tersebut memiliki kontur setinggi 175 centimeter sehingga dapat berfungsi sebagai lantai pada ruangan dan perlindungan bagi telur penyu. Kegiatan sea turtle treatment room dan sea turtle conservatory dapat memanfaatkan area pasir yang menjadi lantai sebagai tempat pelatihan bagi penyu yang mengalami kelainan maupun yang terluka serta bagi tukik. Area tersebut dapat menjadi tempat penyimpanan dan pengawasan telur penyu agar terlindung dari predator. Tempat duduk di area penelitian dan konservasi diberikan bukaan pada lantai sehingga pengunjung tetap dapat merasakan permukaan pasir. Selain itu, hal tersebut berfungsi sebagai pengaliran udara dan meningkatkan kesadaran pengunjung dan peneliti akan lokasi yang terkait. Dengan begitu, pengunjung maupun peneliti tetap dapat merasakan pasir sebagai elemen lingkungan sekitarnya serta ikut mengambil bagian dalam berbagai kegiatan dalam ruang.

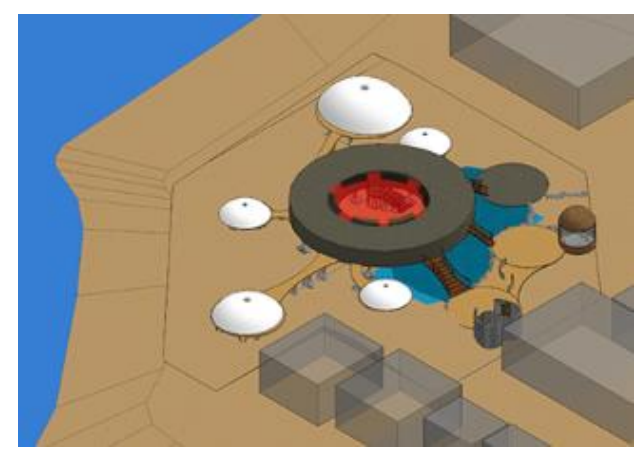

Gambar 10. Massa Multifungsi

Sumber: Penulis, 2021

Bangunan ini menggunakan bentuk lingkaran sebagai bentuk utama dengan tujuan untuk memaksimalkan view ke ruang sekelilingnya dan merupakan implementasi dari bentuk penyu. Bentuk bulat juga merupakan upaya agar semua pengunjung dapat mengakses ruang multifungsi dari berbagai sisi. Massa ini berada di pusat tapak dengan tujuan agar mampu menyatukan seluruh pengunjung dari ruang-ruang sekelilingnya. Massa bagian tengah merupakan bagian dari ruang multifungsi yang dapat digunakan sebagai titik kumpul. Titik kumpul ini dapat difungsikan untuk berbagai kegiatan, baik oleh pengunjung maupun masyarakat Pulau Kelapa Dua. Dengan begitu, ruang multifungsi ini dapat menjadi sarana bagi masyarakatnya untuk memperlihatkan berbagai macam kerajinan tangan maupun budaya yang dimiliki. Area ini dapat juga dimanfaatkan sebagai area penyulingan dan area duduk. Bukaan pada area tengah dapat menjadi sumber pencahayaan dan pengudaraan alami. Dengan potensi ruangan yang akan cukup ramai maka tidak digunakan dinding sebagai pembatas ruangan. 


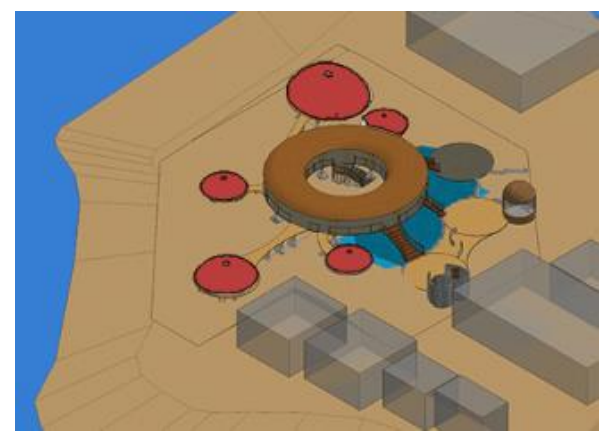

Gambar 11. Massa Sekitar

Sumber: Penulis, 2021

Massa sekelilingnya menggunakan bentuk utama dome yang terinspirasi dari bentuk penyu. Hal ini diharapkan dapat memberikan pengalaman ruang bagi pengunjung akan kondisi di dalam cangkang penyu. Dengan menggunakan bentuk cangkang, pengunjung diajak untuk menjadi bagian dari penyu dan memberikan pengalaman ruang yang berbeda. Pengalaman tersebut diharapkan menjadi proses pembelajaran dan menyadarkan pengunjung akan kondisi penyu yang semakin terlupakan. Selanjutnya, bentuk tersebut diolah menjadi rangka batang yang menyesuaikan dengan material setempat yaitu kayu sebagai salah satu upaya kamuflase.

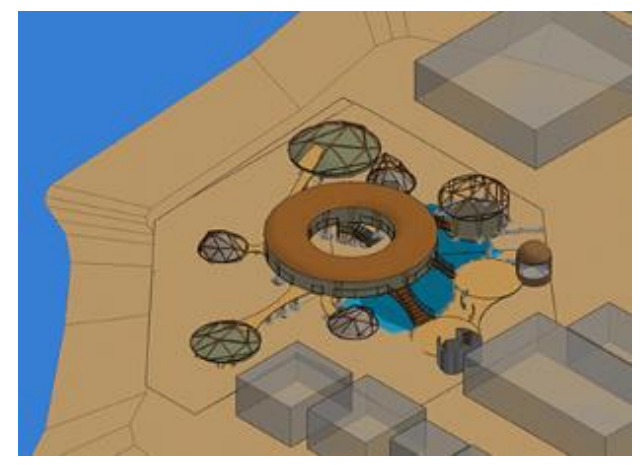

Gambar 12. Rangka Massa Keseluruhan Sumber: Penulis, 2021

Bentuk utama dari rangka berdasarkan pada cangkang penyu yang kemudian diolah menjadi rangka-rangka batang dengan material kayu. Rangka massa dilengkapi dengan tenda sebagai perlindungan bagi pengunjung saat hujan. Penggunaan tenda diharapkan tidak selalu memfokuskan pada kebutuhan pengunjung, melainkan terhadap bagaimana penyu bertahan hidup. Pada waktu tertentu tenda dapat dilipat sehingga meninggalkan rangka kayu utama. Dengan begitu, pengunjung dapat merasakan kondisi lingkungan tanpa terhalang oleh benda yang massive. Rangka tersebut dapat memberikan shading pada ruangan yang seolah menjadi cangkang penyu yang memberikan keteduhan dan perlindungan bagi pengguna ruangnya. Material kayu dapat menjadi elemen kamuflase pada bangunan karena warna dan teksturnya yang mampu menyatu dengan pohon di lingkungan sekitarnya. Pemilihan warna tenda harus mencerminkan lingkungannya terutama karena berada di sekeliling pohon maka, digunakan warna hijau. Pada beberapa ruang lainnya digunakan material tenda yang transparan agar kondisi lingkungannya tetap dapat terlihat dan tidak menghalangi pemandangan pada area pantai. Kedua material ini ditentukan berdasarkan kebutuhan pengguna dan kegiatan akan pencahayaan alami dan buatan pada masing-masing ruang. 


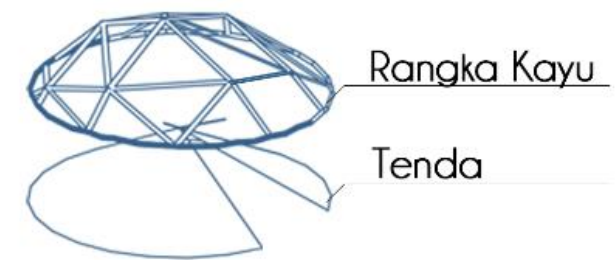

Gambar 13. Bentuk Rangka Sumber: Penulis, 2021

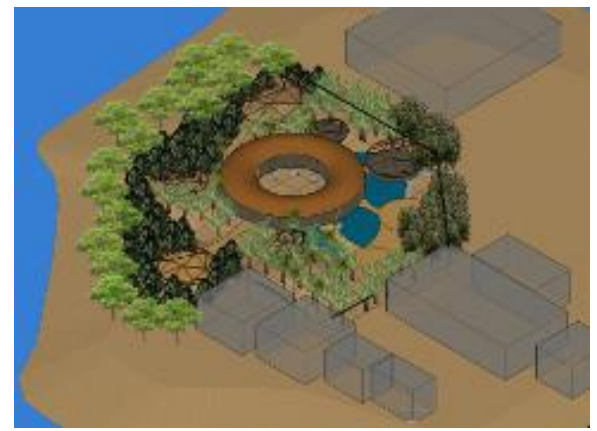

Gambar 14. Pengolahan Massa dan Vegetasi Sumber: Penulis, 2021

Bentuk massa keseluruhan dengan berbagai vegetasi yang menyesuaikan dengan kondisi lingkungannya. Vegetasi tersebut juga berfungsi sebagai upaya berkamuflase dan meningkatkan potensi penyu bertelur serta berkembang biak. Dengan harapan bangunan ini mampu meminimalisir gangguan bagi penyu pada saat melakukan peneluran di sekitar area pantai. Selain itu, pohon dapat mengurangi penyebaran cahaya pada area peneluran yang dapat menjadi gangguan bagi penyu. Pohon dapat memberikan peneduhan selama berlangsungnya proses bertelur.

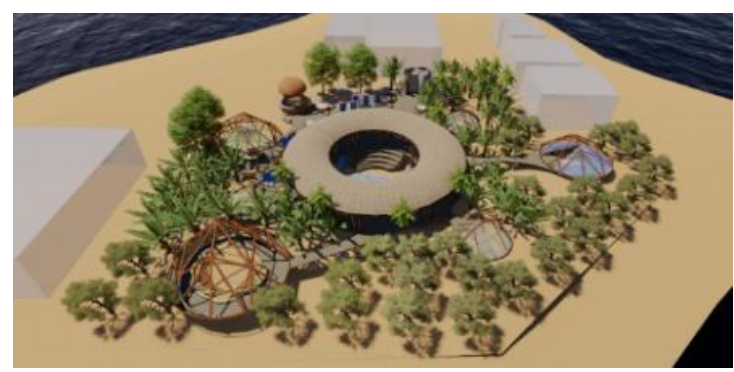

Gambar 15. Bentuk Massa

Sumber: Penulis, 2021

Struktur pada bangunan menggunakan kayu kelapa yang didapat dari lingkungan sekitarnya dan menggunakan tenaga lokal dalam pembangunannya. Pada lantainya menggunakan earthen floor yang merupakan campuran dari tanah liat, pasir, gandum dan minyak. Material ini dipilih sebagai upaya untuk menjaga lingkungan dari penggunaan material yang tidak dapat diolah oleh alam. Material earthen floor dapat meningkatkan wawasan penduduk sekitar. Selain itu, material yang berasal dari area sekitarnya dapat meningkatkan kenyamanan dan potensi penyu bertelur. Warna, material dan vegetasi menjadi pengaruh yang penting terhadap upaya berkamuflase. Ketiga hal tersebut harus mampu merepresentasikan kondisi lingkungan sekitar dan tidak membuat perubahan yang signifikan dari elemen yang telah ada pada lingkungannya. Dengan begitu, kamuflase pada bangunan dapat tercapai dan potensi peneluran penyu pada area pantai dapat meningkat.

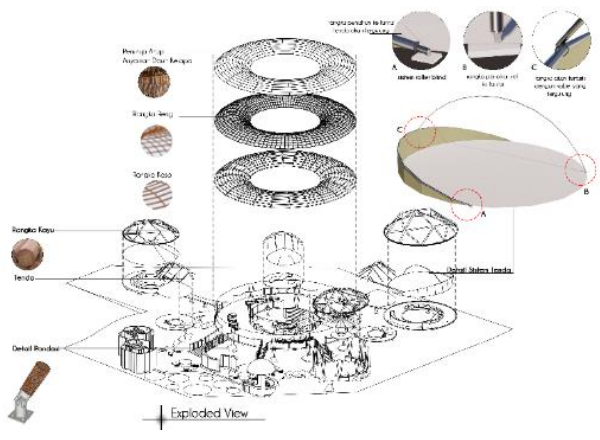

Gambar 16. Sistem Struktur

Sumber: Penulis, 2021 
Rangka kayu menggunakan kayu kelapa yang merupakan material utama di Pulau Kelapa. Pada pondasi digunakan penyangga baja untuk memperkokoh struktur kayu diatasnya. Atap akan ditutup dengan anyaman daun kelapa. Selain itu, untuk tenda otomatis terdapat rangka utama berbentuk setengah lingkaran sebagai rel yang mengatur pergerakan dari roller blind. Detail struktur menggunakan ikatan rotan dengan penyangga utama yaitu angkur besi dan plat besi. Dalam penanganan terkait potensi korosi dapat menggunakan pelapis plastik sebagai salah satu solusi. Pembalutan besi dengan plastik merupakan bentuk pengolahan dan penggunaan kembali sehingga dapat memberikan manfaat bagi manusia maupun lingkungannya. Penggunaan plastik sejalan dengan elemen keberlanjutan secara ekonomi dan lingkungan.

\section{Penerapan Metode Desain Kamuflase pada Bangunan}

Bangunan berkamuflase dengan menutupi bentuknya secara visual sebagai upaya peningkatan kenyamanan penyu untuk bertelur dan perlindungan area sarang penyu. Melalui perspektif mata penyu dapat terlihat bahwa bangunan tertutup oleh beberapa tumbuhan yang selain berfungsi sebagai kamuflase juga dapat memberikan penguatan pada pasir di area bertelur agar tidak mudah runtuh. Dengan begitu, kegiatan pengunjung di dalam bangunan tidak akan terlihat secara langsung pada penyu sehingga kegiatan manusia dan penyu dapat saling berdampingan tanpa terganggu akan keberadaan satu sama lain. Pepohonan seolah menampilkan kondisi alami area pantai tanpa adanya bentuk visual yang mendominasi dari bangunan. Bentuk visual bangunan tersamarkan oleh padatnya pepohonan di area sekitar pantai sehingga penyu tidak akan merasa ragu untuk bertelur karena adanya bangunan yang asing.

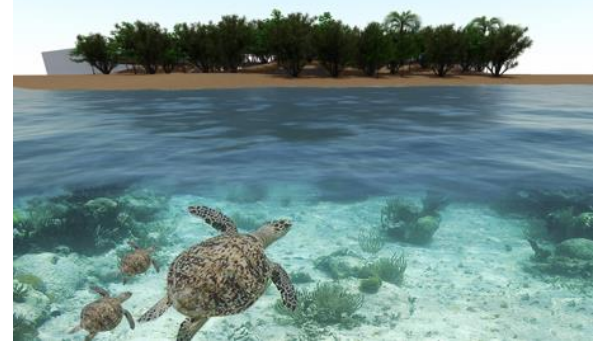

Gambar 17. Perspektif Mata Penyu Sumber: Penulis, 2021

Saat malam hari kegiatan lebih sedikit dan fokus pada observasi peneluran penyu yang dapat terjadi saat malam hari. Oleh karena itu, penggunaan cahaya tidak boleh mendominasi agar penyu tidak terganggu dan proses bertelur dapat proses tersebut akan berlangsung dengan alami. Dengan begitu, pengunjung juga akan terbiasa dengan kondisi gelap dan tetap dapat melakukan observasi di malam hari tanpa menggunakan alat observasi khusus. Proses bertelur penyu dapat menjadi daya tarik wisata sekaligus meningkatkan kesadaran serta kecintaan pada pelestarian penyu. Pengunjung dapat mempelajari bagaimana penyu membentuk sarang hingga bertelur sehingga mampu menambah wawasan pengunjung. Terutama, tanpa penggunaan alat khusus selama pengamatan dan penerangan yang minim menjadikan penyu sebagai fokus utama pengunjung. Dengan begitu, kenyamanan penyu mencapai titik maksimal selama bertelur dan kesadaran penyu akan keberadaan pengamat terminimalisir.

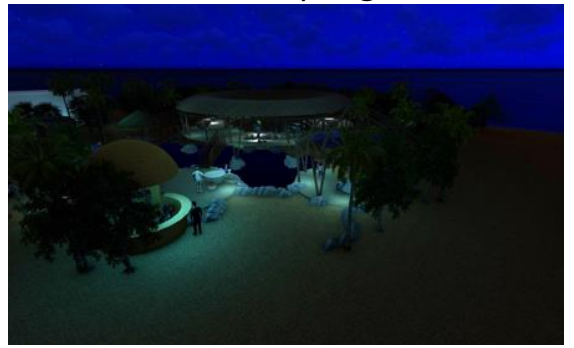

Gambar 18. Perspektif Malam Hari Sumber: Penulis, 2021 
Bentuk rangka penyu meminimalisir bentuk massive dari bangunan serta rangka batang yang berkamuflase menjadi bagian ranting dari pepohonan. Sedangkan, terdapat penggunaan tenda berwarna hijau agar seolah berkamuflase menjadi daun dari pohon dan warna transparan untuk memperlihatkan kondisi sekelilingnya. Dengan begitu, kondisi lingkungan dan pohon-pohon yang ada dapat memberikan kerindangan secara tidak langsung pada ruangan di sekelilingnya. Lalu, pohon dapat menjadi bagian dari elemen kamuflase pada bangunan ditambah dengan penggunaan rangka batang sebagai rangka utama. Selain itu, sebagian besar bangunan bersifat terbuka dan tidak memiliki dinding sehingga penggunaan tiang-tiang kayu dan rangka kayu pada bangunan sangat terlihat dan mampu berkamuflase dengan pohon. Visibilitas ruang-ruang dan pepohonan sekitar tapak dapat dimaksimalkan sehingga pengunjung dapat merasakan kondisi alami lingkungan serta penyu juga tetap dapat mencapai kenyamanannya. Dengan begitu, kamuflase bangunan dapat menjadi maksimal dan kegiatan manusia maupun penyu akan berlangsung secara bersamaan.

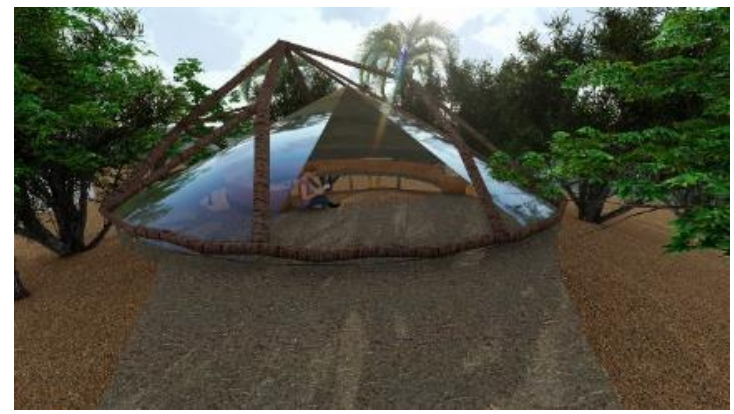

Gambar 19. Perspektif Eksterior Rangka Kayu dan Tenda Sumber: Penulis, 2021

\section{KESIMPULAN DAN SARAN Kesimpulan}

Perancangan ruang tumbuh untuk penyu dan terumbu karang dengan pendekatan metode kamuflase merupakan usaha dalam menyadarkan masyarakat dan pengunjung terhadap kondisi penyu dan terumbu karang di area sekitarnya. Penyesuaian kondisi lingkungan dan dilengkapi dengan metode kamuflase diharapkan mampu meningkatkan kualitas dan kuantitas bagi penyu dan terumbu karang. Terutama, pada kebutuhan penyu untuk melakukan proses bertelur di area pantai dan memberikan penyu ruang agar dapat bertelur dengan nyaman, serta membangun sarang. Penerapan metode kamuflase bangunan diharapkan dapat memberikan inovasi secara visual tanpa melupakan keberlanjutan lingkungan dan ekonomi. Ruang-ruang yang terbentuk memfokuskan pada elemen pohon untuk berkamuflase dan mengelabui penyu dari keberadaan bangunan. Penggunaan warna coklat dengan bentuk cangkang diharapkan dapat tersamarkan karena serupa dengan pohon yang ada di lingkungannya sekaligus sebagai upaya untuk memberikan inovasi secara visual. Lalu, kayu merupakan material yang mudah didapat dan diolah kembali oleh alam sehingga sejalan dengan prinsip keberlanjutan lingkungan pada metode kamuflase. Selain itu, penggunaan tenda transparan maupun berwarna hijau yang merupakan elemen warna dari pohon serta bersifat multifungsi karena sangat menyesuaikan dengan kebutuhan pengunjung yang sesuai dengan prinsip keberlanjutan secara ekonomi. Dengan begitu, akan tercipta keseimbangan antara kegiatan manusia dengan kepentingan dalam menyediakan ruang tumbuh bagi penyu dan terumbu karang yang ada di sekitar nya.

\section{Saran}

Dalam tahap selanjutnya, dapat dilakukan studi lebih lanjut mengenai besar dampak dari aktivitas pengunjung bagi penyu terutama pada area bertelur atau nesting beach. Penggunaan bangunan untuk berbagai aktivitas pengunjung dapat memberikan perubahan akan kondisi 
lingkungan sekitarnya dan apabila kondisi ini mengganggu penyu diperlukan studi lebih lanjut agar kondisi penyu tetap terjaga. Dengan begitu, dampak tersebut memungkinkan akan adanya perubahan dan penyesuaian terhadap kriteria desain sehingga menjadi lebih efektif.

\section{REFERENSI}

Adnyana, I. B. W., dan Hitipeuw, C. (2009). Panduan Melakukan Pemantauan Populasi Penyu di Pantai Peneluran di Indonesia. Jakarta: WWF-Indonesia.

Badan Pusat Statistik Kabupaten Kepulauan Seribu. (2018). Kabupaten Kepulauan Seribu Dalam Angka 2016. Pulau Pramuka Kepulauan Seribu: BPS Kabupaten Kepulauan Seribu.

Barlian, E. dan Umar, I. (2007). Ekologi Manusia. Yogyakarta: Deepublish.

Dewi, A. T. K., dan Yuniartik, M. (2019). Potensi Pantai Cemara, Kabupaten Banyuwangi, Jawa Timur Sebagai Kawasan Ekowisata. Journal of Fisheries and Marine Research Vol. 3.

Habibie, Muhammad N., dan Nuraini, T., A. (2014). Karakteristik Dan Tren Perubahan Suhu Permukaan Laut Di Indonesia Periode 1982-2009. Jurnal Meteorologi Dan Geofisika, 15(1), 37-49.

Hadi, Tri A., Abrar, M ., Giyanto, Prayudha, B., Johan, O., Budiyanto, A., Dzumalek, A. R., Alifatri, L. O., Sulha, S., dan Suharso. (2020). The Status Of Indonesian Coral Reefs 2019. Jakarta: Research Center for Oceanography.

Hoegh-Guldberg, O. (2015). Reviving the Ocean Economy: the case for action - 2015. Geneva: WWF International.

Humke, M. (2011). Tourism and Conservation - Sustainable Models And Strategies. Amerika: USAID.

Kemendikbud. (2021, Agustus 7). Kamus Besar Bahasa Indonesia (KBBI). Diakses melalui KBBI: https://kbbi.web.id/kamuflase.

Kemendikbud. (2021, Agustus 7). Kamus Besar Bahasa Indonesia (KBBI). Diakses melalui KBBI: https://kbbi.web.id/ruang.

Kemendikbud. (2021, Agustus 7). Kamus Besar Bahasa Indonesia (KBBI). Diakses melalui KBBI: https://kbbi.web.id/tumbuh.

Langunan, F., Boneka, F. B., dan Wagey, B. T.. (2017). Aspek Lingkungan Lokasi Bertelur Penyu di Pantai Taturian, Batumbalango Talaud. Jurnal Pesisir dan Laut Tropis Volume 1 Nomor 2.

Mohamed, R. H. (2014). The Challenge of Camouflage in Architecture as Means of Efficiency. Paper presented at The $10^{\text {th }}$ International Conference on Civil and Architecture Engineering, Civil and Arch Branch, Egypt.

Moein, S. B., dan Musick, J. A. (2002). Sensory Biology of Sea Turtles. The Biology of Sea Turtles Vol. 2. melalui Research Gate https://www.researchgate.net/publication/264839963_Sensory_Biology_of_Sea_Turtles.

Mukharomah, Ervina. (2021). Konsep Dasar Ekologi Tumbuhan. Palembang: Bening Media Publishing.

Palenteng, Willy. (2017). Preferensi Wisatawan Dki Jakarta Di Kawasan Kepulauan Seribu Jakarta. Proyek Akhir. Sekolah Tinggi Pariwisata. Bandung.

Ridhwan, M. J. (2017). Penyu dan Usaha Pelestariannya. Jurnal Serambi Saintia Vol. 5(1).

Roemantryo, Nastiti, A. S., dan Wiadnyana, N. N. (2012). Struktur dan Komposisi Vegetasi Sekitar Sarang Penyu Hijau (Chelonia mydas Linnaeus) Pantai Pangumbahan, Sukabumi Selatan, Jawa Barat. Berita Biologi 11 (3).

Salim, Dafiuddin. (2012). Pengelolaan Ekosistem Terumbu Karang Akibat Pemutihan (Bleaching) Dan Rusak. Jurnal Kelautan Vol. 5 No. 2.

Sosilowati, Handayani, A., Wahyudi, A. R., Massudi, W., Febrianto, S., dan Suhendri, N. A. (2017). Sinkronisasi Program Dan Pembiayaan Pembangunan. Jakarta: Pusat Pemrograman dan Evaluasi Infrastruktur PUPR.

Sutanto, A. (2020). Peta Metode Desain.

Tomasick, T., Mah, A. J., Nontji, A., dan Moosa, M. K. (1997). The Ecology of The Indonesia Seas Part II. Singapore: Periplus Edition.

Yudhantoko, M., Handoyo, G., dan Zainuri, M. (2016). Karakteristik dan Peramalan Pasang Surut Pulau Kelapa Dua, Kabupaten Kepulauan Seribu. Jurnal Oseanografi Vol. 5 No. 3. Diakses melalui: https://ejournal3.undip.ac.id/index.php/joce/article/view/15359/14851 